\title{
Effectiveness of Marketing Mix Strategies on Customer Satisfaction, Loyalty and Retention in Banking: Case Study of Zenith Bank PIc, Nigeria
}

\author{
Elma Asekome (MISS) \\ BSc Accounting, AAU, \\ MSc Financial Services Management, University of Salford \\ Marketing Department, Zenith Bank Plc, Ilupeju, Lagos, Nigeria.
}

\begin{abstract}
The objective of this study was to ascertain the effectiveness of Zenith Bank marketing mix strategies on customer satisfaction, loyalty and retention and how to improve on them. Data were collected from primary sources through a questionnaire made up of descriptive options in a 5- scale Likert research format. The data were subjected to empirical analysis using the SPSS software to estimate the mean distribution, standard deviation, Pearson's correlation coefficient, analysis of variance (ANOVA) as well as multiple regression analysis to test the set hypotheses. The result of the analysis revealed that though each of the elements of the marketing mix strategies influences the effectiveness of Zenith Bank marketing, product, process and personnel were more significant in contributing to meeting customer satisfaction, customer loyalty and customer retention. The study recommended the need for the Bank to continue to improve on these significant strategies as well as improving on other strategies that could attract, meet and exceed customer expectations such as enhancing transaction process flow, continuous training of the Bank personnel and providing the latest technological innovations to ensure error free transactions. The study further recommended the need to increase the Bank corporate social responsibility by sponsorship of social events that could increase its marketing visibility as well as avoiding incidences of cash shortage at ATM points to reduce customer complaints.
\end{abstract}

Key words: 'Effectiveness', 'Marketing mix strategies', Customer Satisfaction', 'Loyalty and Retention'.

\section{BACKGROUND TO THE STUDY}

There has been growing competition in the banking sector in Nigeria in the last decade resulting from the increasing proliferation of many financial institutions, growing customer sophistication, and demand for higher quality of banking services (Anyim:2018). In the presence of such growing trends in bank marketing competition, customer satisfaction becomes more demanding(Areo:2015) and thus marketing organizations need to offer higher quality services coupled with an effective marketing mix strategy to meet customer satisfaction and loyalty (Kotler \& Keller:2009).

Kotler and Armstrong (2010) suggest that customer satisfaction and loyalty depends on the effectiveness of their marketing mix strategies.

In spite of the several reforms and the increasing deployment of information communication technology to banking transactions and the introduction of new products and services that call for various marketing strategies in Nigeria there have complaints of poor services such as long waits at ATM cash points (Ogege and Williams, 2014) as well as complaints of poor pricing such as the wide gap between deposit and lending rates. Other complaints include customer unauthorized debiting, inadequate ATM service points, poor information content in bank 
promotional strategies and delays in turn-around time for banking transactions (Ogunnaike and Ogbari, 2008).

Available studies in Nigeria on this topic have not specifically addressed the relevant questions on whether customers are satisfied based on the elements of the bank marketing mix strategies. The few studies identified in the literature in Nigeria including those of Sokefun (2014), Nwankwo (1991), Onyefunji (2003), Oni (2002), Ojo (2012), Akinyele (2011), and Adebowale (2015) did not specifically address the topic on whether the marketing mix strategies were effective and how they could be improved upon in the banking sector.

Attempting to find answers to these questions requires an indebt research to ascertain the effectiveness of bank marketing mix strategies and how to improve on them to enhance customer satisfaction, loyalty, and retention in the banking industry in Nigeria.

The main objective of this study is to ascertain the effectiveness of Zenith Bank marketing mix strategies on customer satisfaction, loyalty, and retention and to suggest ways of improvement. The specific objectives are:

1. To ascertain the effectiveness of Zenith Bank marketing mix strategies in enhancing customer satisfaction

2. To examine the extent to which Zenith Bank marketing mix strategies are effective in enhancing customer loyalty

3. To investigate the extent to which Zenith Bank marketing mix strategies are effective in in enhancing customer retention

\section{Research Hypotheses}

1. Zenith marketing mix strategies are not effective in enhancing customer satisfaction.

2. Zenith Bank marketing mix strategies are not effective in enhancing customer loyalty.

3. Zenith Bank marketing mix strategies are not effective in enhancing customer retention.

\section{Profile of Zenith Bank Plc}

Zenith Bank is a multinational financial services provider licensed by the Central Bank of Nigeria in May 1990 and commenced banking business in July 1990. Zenith Bank: https://www.zenithbank.com accessed 6 ${ }^{\text {th }}$ October 6, 2018.

It became a public liability company in 2004 with shares listed on the Nigerian Stocks Exchange. In 2013, \$850 million worth of its shares were listed on the London Stock Exchange at $\$ 6.80$ per share. (Zenith Annual Financial Report: 2017)

The Bank has over 500 branches distributed in all the states in Nigeria. The bank has subsidiaries in the United Kingdom, Ghana, The Gambia, Sierra Leone, United Arab Republic and representative offices in South Africa and China. (Zenith Annual Financial Report: 2017).

\section{CONCEPTUAL REVIEW OF MARKETING LITERATURE}

The essence of the concept of marketing is to identify customer needs and how to satisfy these needs at a profit to the organization providing the needs. Lambin (2013) defines marketing as anchored on three pillars consisting of customer orientation, integration efforts and profit expectation. Kotler and Keller (2006) defines marketing as the process of providing services that meet customer needs or satisfaction, while Kotler and Armstrong (2010) sees marketing as creating long term customer relationship and retention. 
In service marketing organizations, three additional Ps have been introduced as suggested by Boom and Bitner (1981) to reflect the unique nature characteristics of the services such as intangibility, variability, heterogeneity and inseparability that place emphasis on people, process and personnel. However, in banking, less emphasis is placed on tangibility and more on intangibles as it involves dealing with a large number of intangible products and services and a large number of customers that require personalized services. The marketing mix strategies of banking thus include products, price, promotion, physical places (or evidence), the bank personnel, and the people being serviced as well as the process of transaction which in this research are summarized into 6Ps of marketing.

\section{Theoretical Review of Literature}

\section{Porter's Generic Strategy Theory}

The Porter's Generic Strategy model consists of three components (Porter, 1985)

(i) Cost leadership

(ii) Differentiation and

(iii) Cost focus

Pokharel (2011) noted that cost leadership is within the broad strategy target in which the company provides services at the lowest possible cost among competitors by taking advantage of scale economies, innovative technology and effective service delivery. The differentiation strategy according to Pokharel (2011), suggests that differential strategy encourages the company to provide unique services and presented with focus on customer targeting strategy with the aim of reaching out specifically with unique services to individual customers. The cost focus emphasizes on effectiveness, efficiency and cost reduction in providing satisfactory services to various groups of customers.

\section{Value Discipline Theory}

Treacy and Wieserma (1996) proposed the "Value Discipline Model" which is an important market positioning tool with three combined strategies (Pokharel, 2011):

(i) Operational excellence that targets cost reduction through efficient allocation, positioning at economic scale to achieve service quality at a lower service cost.

(ii) Service leader targeting service quality differentiation and service quality.

(iii) Customer intimacy targeting closeness to get more information about the customer to ensure service quality, satisfaction and loyalty (Verhoef \& Langerak (2002).

\section{The Customer Pyramid Theory}

The customer pyramid involves selecting customers into profitability tiers and providing service tailored to achieve higher performance levels. The selected customers with the highest prospects are given prime service while middle and lower levels prospects are given relevant service attention to enable them attain higher performance. Customers considered unprofitable are specially managed or discarded to reduce cost (Zeithaml, Rust \& Lemon (2001).

\section{Customer Loyalty Ladder Theory}

The loyalty ladder is a relationship marketing concept that sees customer gradually moving up through relationship levels starting at the bottom as prospects that have the intent to purchase and ending up at the top as advocates (Marie-Guzzoni (2005).

\section{The Service Marketing Triangle Theory}

Gronroos (2000) proposed the Service Marketing Triangle of service quality. He demonstrated in a triangular diagram that there are different levels of marketing such as internal marketing 
which is between the firm (management) and the employees consisting of front line staff and support staff, interactive marketing which is between the employees and the customers at which level there are expectations and perceptions of service quality as well as external marketing between the management of the firm and customers at which level there are expectations and perceptions of service quality.

\section{Theories of Marketing Mix Strategies Service Quality Gaps Theory}

Parasuaman, Zeithaml, and Berry (1985) and Lovelock and Wirtz (2000) modeled the various gaps between customer perception and expectation (P-E) where P and E represents perception and expectation respectively on various dimensions of such as the difference between customer expectation and management perception and customer expectation, knowledge gap as well as the difference between service actually delivered and the promise communicated to customers known as promotional activities communication gap.

These gaps show that the effectiveness of marketing mix strategies(product, price, promotion, place, physical and personnel) can be influenced by gaps arising between perceptions and expectations at the level of management of the organization, as well as the personnel (staff) and people(customers) of the organization that could go a long way to create gaps in customer satisfaction. These gaps need to be addressed to ensure effectiveness of marketing mix strategies on customer satisfaction and loyalty.

\section{EMPIRICAL REVIEW}

Oyefunji (2003) studied capacity building for universal banking and the challenge of human capital finds a significant relationship between company performance and customer satisfaction. Although the conclusion was need for capacity building for effective marketing to satisfy bank customers, the study did not specifically address the relationship between customer satisfaction and effectiveness of marketing mix strategies.

Adebowale (2015) investigated marketing of banking services and consumer satisfaction in Nigeria revealing that customer satisfactions based on turn-around time were generally below average of expectation. The study also did not dwell on marketing mix strategies in estimating customer satisfaction. This implies that there was a gap between customer expectation and actual satisfaction.

Akinyele and Opeyemi (2011) reviewed impact of market strategies on bank performance in Nigeria using questionnaire survey, t-test, and Pearson Product Management and correlation to test the hypothesis that marketing strategies had correlation with quality of marketing and to discover if marketing strategies create awareness to customers. The study also examined if profitability depends on marketing strategies and whether competition had a positive impact on banks. Though the studies found positive correlation between the dependent and independent variables, the researchers did not go further to examine the relationship between customer satisfaction and the individual elements in the marketing mix strategy.

Astin (1993) studied customer satisfaction as mentioned in Ogunnaike, Borishade etal (2014) finding a positive relationship between customer satisfaction and customer retention. However, the study did not disaggregate customer satisfaction the various variables in the relation between customer satisfaction and effectiveness of marketing mix strategies in the Nigerian banking industry. 
Adebowale (2015) explored marketing of banking services and consumer satisfaction in Nigeria revealing that customer satisfaction based on bank retail, focus and turn-around time were generally below average of expectation. The study did not go further to estimate the level of customer satisfaction and the effects of marketing mix strategies on customer satisfaction.

\section{Gaps Identified in the Literature}

From the empirical review as discussed above, it appears that though many studies have been carried out in other countries on the relationship between customer satisfaction and the several elements in the marketing mix strategies, not many of such studies were carried out in Nigeria. The few studies found in the literature in Nigeria have not empirically focused on the effectiveness of the 7 Ps elements in the bank marketing mix strategies and how to improve on them even in the face of growing competition, customer sophistication and banking sector reforms that have been trending in Nigeria. It is this knowledge gap that this study attempts to address.

\section{Research Design}

\section{METHODOLOGY}

The Likert 5-scale instrument is used to collect primary data from the 400 customers randomly and purposely selected from various branches of Zenith Bank to provide answers to certain questions raised in the research.

\section{Sampling Techniques}

In this study, the purposive research technique is adopted in the questionnaire distribution. The purposive or convenience sampling technique is a non-probability sampling technique that is adopted in selecting the required number of respondents from a large or infinite population (Bryman and Bell 2005). This method was chosen because it makes it possible to include respondents who are in position to provide relevant answers to meet the purpose of the research (Saunders et al:2009) and

\section{Research Instrument}

The instrument for the primary data collection is a questionnaire made up of description options in a 5 scale Likert research format. It enables a respondent to give his or her perception about each particular question with options ranging from Strongly Agree, Agree, Not Sure, Disagree and Strongly Disagree.

\section{Reliability of the Research Instrument}

To ascertain the reliability of the instrument in this study, the two-step method of questionnaire administration was adopted by first taking a small sample of 20 respondents in a pilot study and thereafter the second step of administering the entire questionnaire to respondents. From the test sample of 20 respondents, Cronbach's coefficient alpha was used to test the internal consistency and reliability of the instrument and was found to be 0.915 which is well above the minimum acceptable value of 0.7 as suggested by Nunnally (1978). This indicates that the instrument is reliable for data collection and analysis.

\section{Methods of Data Analysis}

Analysis of data was carried out using two methods. The data extracted from the questionnaire were first analyzed using the Statistical Package for Social Sciences (SPSS) version16 to obtain the means, standard deviations and correlation matrix. This was followed by the multiple regression analysis using the ordinary least squares regression (OLS). The OLS method was chosen for this study because it has the advantage of unbiasedness, efficiency and consistency and therefore regarded as best linear estimator (BLUE). It is able to estimate the coefficients of 
the variables and able to detect their respective significant effects on the dependent variable (Iyoha: 2004) The estimated results from the OLS were further evaluated using statistical individual significant test (t-test), overall statistical significant tests (F-test). The goodness of fit of the model adopted was further be tested by the use of the coefficient of determination(Rsquared).

\section{Model Specifications}

The hypothetical relationship that was investigated in this study is that customer satisfaction, customer loyalty and customer retention depended on the 6Ps of marketing. Satisfied customers would be loyal to the bank. Loyalty brings repeat patronage and thus long-term relationship (retention). Therefore, the effectiveness of the marketing mix strategy determines customer satisfaction, loyalty and retention. If CUS, CUL and CUR are high, that means the marketing mix strategies are effective. Expressed in mathematical function therefore, customer satisfaction, loyalty and retention are a function of the effectiveness of marketing mix strategy.

Where:

$$
\text { EMS }=\mathrm{f}(\mathrm{CUS}, \mathrm{CUL} \text { and CUR) }
$$

CUS, CUL, and CUR, represent customer satisfaction, customer loyalty and customer retention respectively and EMS represents effectiveness of marketing mix strategies. The above relationship can further be disaggregated as presented in three separate functions as follows:

$$
\begin{aligned}
& \text { Customer Satisfaction (CUS) }=\mathrm{f}\left(\mathrm{p}_{1}, \mathrm{P} 2, \mathrm{P} 3, \mathrm{P} 4, \mathrm{P} 5, \mathrm{P} 6\right) \\
& \text { Customer Loyalty (CUL) }=\mathrm{f}\left(\mathrm{p}_{1}, \mathrm{P} 2, \mathrm{P} 3, \mathrm{P} 4, \mathrm{P} 5, \mathrm{P} 6\right) \\
& \text { Customer Retention (CUR) }=\mathrm{f}\left(\mathrm{p}_{1}, \mathrm{P} 2, \mathrm{P} 3, \mathrm{P} 4, \mathrm{P} 5, \text { P }\right)
\end{aligned}
$$

Since the effectiveness of marketing strategy mix (ESM) is a function of customer satisfaction, loyalty and retention, then the general function can be written as:

$$
\mathrm{ESM}=\mathrm{f}(\mathrm{CUS}, \mathrm{CUL}, \mathrm{CUR})
$$

Expressed mathematically, the general function can be modeled as follows:

$$
\mathrm{ESM}=\propto_{0}+\propto_{1} P_{1}+\propto_{2} P_{2}+\propto_{3} P_{3}+\propto_{4} P_{4}+\propto_{5} P_{5}+\propto_{6} P_{6}+e_{i}
$$

Where: ESM = Effectiveness of marketing strategy mix

$\propto_{0}=$ Constant term representing the intercept on the $\mathrm{x}$-axis

$\mathrm{P}_{1}=$ product, $\mathrm{P}_{2}=$ price, $\mathrm{P}_{3}=$ Place, $\mathrm{P}_{4}=$ promotion, $\mathrm{P}_{5}=$ personnel, $\mathrm{P}_{6}=$ process, $\mathrm{e}_{\mathrm{i}}=$ error term . Appriori expectation, $\propto_{1}$ to $\propto_{1}>0$

\section{Demographic Statistics of Respondents}

\section{DATA ANALYSIS}

The demographic variables of the respondent show that out of the 378 questionnaires correctly filled and returned, $210\{57 \%\}$ were males and $166\{44 \%\}$ were females. The age distribution showed that 140 (37\%) were above 40 years old, 134 respondents (35.4\%) were between 30-40years, while 104 (27.5\%) were below 30 years. Of these 378 respondents, 279 (73.8\%) were married while the rest were either single or divorced as indicated in Table 4.01 below.

The variables also showed that 155 (41\%) of the respondents were current account holders while the rest had savings and other type of account. Regarding the duration of account 
relationship with the Bank, 116 (33.7\%) had been customers to Zenith for over 10 years, 128 $(33.9 \%)$ held account for 5-10 years and others below 5 years as indicated in Table 4.01 below.

\section{Descriptive Statistics of Customer Satisfaction}

Of the 378 respondents, a total of 300 (79.3\%) with a mean of 3.6561 either agreed or strongly agreed that they were satisfied with Zenith product/services while 224 (59.3\%) with a mean of 3.4048) agreed or strongly agreed that they were satisfied with Zenith pricing. On Branch location and physical evidence, 291 (76\%) with a mean of 3.8624 agreed or strongly agreed that they were satisfied with Zenith branch locations and physical evidence as indicated in Table 4.02 below. Out of the 378 respondents, a total of 211 (55.8\%) with a mean of 3.3439 either agreed or strongly agreed that they were satisfied with Zenith promotional strategies while $289(76.5 \%)$ with a mean of 3.7249 agreed or strongly agreed that they were satisfied with Zenith staff disposition in providing services to customers. Also, of the 378 respondents, a total of 259 (68.5.3\%) with a mean of 3.6561 either agreed or strongly agreed that they were satisfied with Zenith process and procedures

\section{Pearson Correlation Analysis of Customer Satisfaction}

The Pearson correlation analysis examines the degree of association between variables in our model on marketing mix strategies. The Pearson correlation coefficient lies between -1 and +1 . A positive value indicates that when one variable increases or decreases the other variable behaves the same way but a negative value indicates the opposite although this does not indicate causality between the variables. A high correlation coefficient means that there is a close relationship in the behavior of the two variables. For example, the relationship between customer satisfaction and Zenith Bank pricing strategy is negative at $1.5 \%$ while the association between product and pricing is $17.2 \%$. Also, the association between process strategy and personnel is $68.8 \%$. The negative association between price and customer satisfaction implies that there will be a decrease in customer satisfaction if price increases to an extent of $1.5 \%$. However, if there is an increase in process, there shall also be an increase in customer satisfaction to an extent of $68.8 \%$. Other trends in the relationship among the marketing mix strategies are indicated in Table 4.05 below and are significant at $5 \%$ level of significance. 
Table 4.06 Pearson Correlations Matrix on Customer Satisfaction

\begin{tabular}{|ll|c|c|c|c|c|c|c|}
\hline & & CUS & P1 & P2 & P3 & P4 & P5 & P6 \\
\hline Pearson Correlation & CUS & 1.000 & .124 & -.015 & -.028 & -.005 & -.036 & -.175 \\
& P1 & .124 & 1.000 & .172 & .426 & .337 & .327 & .343 \\
& P2 & -.015 & .172 & 1.000 & .292 & .297 & .382 & .339 \\
& P3 & -.028 & .426 & .292 & 1.000 & .547 & .430 & .402 \\
& P4 & -.005 & .337 & .297 & .547 & 1.000 & .600 & .488 \\
& P5 & -.036 & .327 & .382 & .430 & .600 & 1.000 & .688 \\
& P6 & -.175 & .343 & .339 & .402 & .488 & .688 & 1.000 \\
\hline Sig. (1-tailed) & CUS &. & .008 & .386 & .290 & .463 & .240 & .000 \\
& P1 & .008 &. & .000 & .000 & .000 & .000 & .000 \\
& P2 & .386 & .000 &. & .000 & .000 & .000 & .000 \\
& P3 & .290 & .000 & .000 &. & .000 & .000 & .000 \\
& P4 & .463 & .000 & .000 & .000 &. & .000 & .000 \\
& P5 & .240 & .000 & .000 & .000 & .000 &. & .000 \\
& P6 & .000 & .000 & .000 & .000 & .000 & .000 &. \\
\hline CUS & 378 & 378 & 378 & 378 & 378 & 378 & 378 \\
& P1 & 378 & 378 & 378 & 378 & 378 & 378 & 378 \\
& P2 & 378 & 378 & 378 & 378 & 378 & 378 & 378 \\
& P3 & 378 & 378 & 378 & 378 & 378 & 378 & 378 \\
& P4 & 378 & 378 & 378 & 378 & 378 & 378 & 378 \\
& P5 & 378 & 378 & 378 & 378 & 378 & 378 & 378 \\
P6 & 378 & 378 & 378 & 378 & 378 & 378 & 378 \\
\hline
\end{tabular}

\section{Interpretation of Findings}

\section{Correlation between Customer Satisfaction and the 6Ps of the marketing mix strategy}

The unstandardized coefficients show how much the dependent variable (Customer satisfaction varies with each of the independent variables in the marketing mix (Product, price, place, promotion, personnel and process) assuming that all other variables were constant. As indicated in Table 4.07 below, this gives $82.3 \%, 7.90 \%, 24.6 \%, 15.7 \%, 36.2 \%$ and $86.1 \%$ respectively for product, price, place, personnel and process showing that product and process are very important and significant at $5 \%$ level in the marketing mix strategies. The beta coefficients indicate the extent to which each of the elements of the marketing mix strategies influences customer satisfaction hence the two most influential factors were product (20.8\%) and process (32.8\%), followed by personnel (11.3\%). However, only product and process were significant at $5 \%$ level of significance as shown in Table 4.07 below. 
Table 4.07 Correlation Coefficients of Customer Satisfaction

\begin{tabular}{|c|c|c|c|c|c|c|c|}
\hline \multirow[b]{2}{*}{ Model } & \multicolumn{2}{|c|}{ Unstandardized Coefficients } & \multirow{2}{*}{$\begin{array}{c}\text { Standardized } \\
\text { Coefficients }\end{array}$} & \multirow[b]{2}{*}{$\mathrm{T}$} & \multirow[b]{2}{*}{ Sig. } & \multicolumn{2}{|c|}{$95 \%$ Confidence Interval for B } \\
\hline & B & Std. Error & & & & Lower Bound & Upper Bound \\
\hline (Constant) & 20.338 & 2.569 & & 7.916 & .000 & 15.286 & 25.390 \\
\hline $\mathrm{P} 1$ & .823 & .223 & .208 & 3.689 & .000 & .384 & 1.262 \\
\hline P2 & .079 & .189 & .023 & .420 & .675 & -.292 & .450 \\
\hline P3 & -.246 & .235 & -.066 & -1.046 & 296 & -.709 & .217 \\
\hline P4 & .157 & .227 & .047 & 689 & 491 & -.290 & .603 \\
\hline P5 & .362 & .246 & .113 & 1.470 & 142 & -.122 & .846 \\
\hline P6 & -.861 & 185 & -.328 & -4.652 & .000 & -1.225 & -.497 \\
\hline
\end{tabular}

a. Dependent Variable: CUS

Source: Researcher's computations (2018) SPSS, VERSION 16

\section{Regression Analysis}

The Multiple Regression Model examines the nature of the relationship between customer satisfaction and the various elements in the marketing mix strategies as stated in the research hypotheses of this study. There are four regression models being examined in this study, one each for customer satisfaction (CUS), customer loyalty (CUL) and customer retention (CUR). In the $4^{\text {th }}$ model (Effectiveness of marketing mix strategies (EMS) is the overall dependent variable while the combined effects of CUS, CUL and CUR become the independent or explanatory variables that determines the effectiveness of the marketing mix strategies.

$$
\mathrm{ESM}=\propto_{0}+\propto_{1} P_{1}+\propto_{2} P_{2}+\propto_{3} P_{3}+\propto_{4} P_{4}+\propto_{5} P_{5}+\propto_{6} P_{6}+e_{i}
$$

The regression correlation coefficient shows the degree of relationship between the dependent and independent variables The coefficient of determination $\left(\mathrm{R}^{2)}\right.$ indicates the goodness of fit for each of the models. It is the power of explanation showing the extent to which changes in the dependent variables (EMS) are explained by the independent variables that make up the marketing mix strategy.

Based on these explanations, the regression results for each of the 4 models are discussed below.

\section{Relationship between Customer Satisfaction and Marketing Mix Strategies}

The regression coefficient (R) is $28.4 \%$ which means that there is a $28.4 \%$ positive relationship between CUS and the 6Ps of the marketing mix strategy. The coefficient of determination (R2) which $8 \%$ as shown in the models for CUS is the extent to which the independent variables (the $6 \mathrm{Ps}$ ) accounted for changes in the customer satisfaction. The F-statistic of 5.406 is significant at $5 \%$ level of error with a probability of 0.000 is less that $5 \%$ or 0.05 . This means that there is a positive and significant relationship between customer satisfaction and the marketing mix strategies in Zenith Bank Plc as shown in Table 4.11 below. This implies that Zenith marketing mix strategies are effective in terms of customer satisfaction. 
Table 4.11: Model Summary

\begin{tabular}{|c|c|c|c|c|c|c|c|c|c|c|}
\hline \multirow[b]{2}{*}{ Model } & \multirow[b]{2}{*}{$\mathrm{R}$} & \multirow[b]{2}{*}{ R Square } & \multirow[b]{2}{*}{$\begin{array}{l}\text { Adjusted R } \\
\text { Square }\end{array}$} & \multirow[b]{2}{*}{$\begin{array}{l}\text { Std. Error of } \\
\text { the Estimate }\end{array}$} & \multicolumn{5}{|c|}{ Change Statistics } & \multirow[b]{2}{*}{$\begin{array}{l}\text { Durbin- } \\
\text { Watson }\end{array}$} \\
\hline & & & & & $\begin{array}{l}\text { R Square } \\
\text { Change }\end{array}$ & F Change & df1 & df2 & Sig. F Change & \\
\hline 1 & $.284 \mathrm{a}$ & .080 & .066 & 4.78663 & .080 & 5.406 & 6 & 371 & .000 & 1.745 \\
\hline
\end{tabular}

a. Predictors: (Constant), P6, P2, P1, P3, P4, P5

b. Dependent Variable: CUS

Source: Researcher's Computation: SPSS.16

\section{Relationship between Customer Loyalty Marketing Mix Strategies}

The regression coefficient(R) is $27.6 \%$ which means that there is a $27.6 \%$ positive relationship between CUL and the 6Ps of the marketing mix strategy. The coefficient of determination (R2) which $7.6 \%$ as shown in the models for CUS is the extent to which the independent variables (the 6Ps) accounted for changes in the customer loyalty. The F-statistic of 5.086 is significant at $5 \%$ level of error with a probability of 0.000 is less that $5 \%$ or 0.05 . This means that there is a positive and significant relationship between customer loyalty and the marketing mix strategies in Zenith Bank Plc as shown in Table 4.12 below. This implies that Zenith marketing mix strategies are effective regarding customer loyalty.

Table 4.12: Model Summary

\begin{tabular}{|c|c|c|c|c|c|c|c|c|c|c|}
\hline \multirow[b]{2}{*}{ Model } & \multirow[b]{2}{*}{$\mathrm{R}$} & \multirow[b]{2}{*}{ R Square } & \multirow[b]{2}{*}{$\begin{array}{l}\text { Adjusted R } \\
\text { Square }\end{array}$} & \multirow[b]{2}{*}{$\begin{array}{l}\text { Std. Error of } \\
\text { the Estimate }\end{array}$} & \multicolumn{5}{|c|}{ Change Statistics } & \multirow[b]{2}{*}{$\begin{array}{l}\text { Durbin- } \\
\text { Watson }\end{array}$} \\
\hline & & & & & $\begin{array}{l}\text { R Square } \\
\text { Change }\end{array}$ & F Change & df1 & df2 & $\begin{array}{c}\text { Sig. F } \\
\text { Change }\end{array}$ & \\
\hline 1 & $.276^{a}$ & .076 & .061 & 4.31753 & .076 & 5.086 & 6 & 371 & .000 & 1.664 \\
\hline
\end{tabular}

a. Predictors: (Constant), P6, P2, P1, P3, P4, P5

b. Dependent Variable: CUL

\section{Source: Researcher's Computation (2018) using SPSS.16}

\section{Relationship between Customer Retention and Marketing Mix Strategies}

The regression coefficient(R) is $28.7 \%$ which means that there is a $28.7 \%$ positive relationship between CUR and the 6Ps of the marketing mix strategy. The coefficient of determination $\left(\mathrm{R}^{2}\right)$ which $8.2 \%$ as shown in the models for CUS is the extent to which the independent variables (the 6Ps) accounted for changes in the customer loyalty. The F-statistic of 5.540 is significant at $5 \%$ level of error with a probability of 0.000 is less that $5 \%$ or 0.05 . This means that there is a positive and significant relationship between customer retention and the marketing mix strategies in Zenith Bank Plc as shown in Table 4.13 below. This implies that Zenith marketing mix strategies are effective in terms of customer retention.

Table 4.13: Model Summary

\begin{tabular}{|c|c|c|c|c|c|c|c|c|c|c|}
\hline \multirow[b]{2}{*}{ Model } & \multirow[b]{2}{*}{$\mathrm{R}$} & \multirow[b]{2}{*}{ R Square } & \multirow[b]{2}{*}{$\begin{array}{l}\text { Adjusted R } \\
\text { Square }\end{array}$} & \multirow[b]{2}{*}{$\begin{array}{l}\text { Std. Error of } \\
\text { the Estimate }\end{array}$} & \multicolumn{5}{|c|}{ Change Statistics } & \multirow[b]{2}{*}{ Durbin-Watson } \\
\hline & & & & & $\begin{array}{l}\text { R Square } \\
\text { Change }\end{array}$ & F Change & df1 & df2 & Sig. F Change & \\
\hline 1 & $.287 \mathrm{a}$ & .082 & .067 & 4.59772 & .082 & 5.540 & 6 & 371 & .000 & 1.575 \\
\hline
\end{tabular}

a. Predictors: (Constant), P6, P2, P1, P3, P4, P5

b. Dependent Variable: CUR

Source: Researcher's Computation (2018) using SPSS.16 


\section{DISCUSSION OF FINDINGS}

Each of these hypotheses was tested separately and thereafter, the three were combined and test against the overall effectiveness of Zenith marketing mix strategies.

On customer satisfaction, the beta coefficients indicate the extent to which each of the elements of the marketing mix strategies influences customer satisfaction. The two most influential factors were product (20.8\%) and process (32.8\%), followed by personnel $(11.3 \%)$. However, only product and process were significant at 5\% level of significance as shown in Table 4.07. This agrees with the findings of Cengiz and Yayla (2007) in Turkey. The findings in this study agree with the findings of Adeleye and Adeleke (2015) that there was a significant positive relationship between service marketing mix and of the consolidated banks performance in Nigeria.

On customer loyalty, the regression coefficient(R) is $27.6 \%$ which means that there is a $27.6 \%$ positive relationship between CUL and the 6Ps of the marketing mix strategy. The F-statistic of 5.086 is significant at $5 \%$ level of error with a probability of 0.000 that is less that $5 \%$ or 0.05 . This means that there is a positive and significant relationship between customer loyalty and the marketing mix strategies in Zenith Bank Plc as shown in Table 4.07 below. This implies that Zenith marketing mix strategies are effective regarding customer loyalty hence the alternative hypothesis is rejected.

On customer retention, the F-statistic of 5.540 is significant at $5 \%$ level of error with a probability of 0.000 is less that $5 \%$ or 0.05 . This means that there is a positive and significant relationship between customer retention and the marketing mix strategies in Zenith Bank Plc as shown in Table 4.13. This implies that Zenith marketing mix strategies are effective in terms of customer retention and hence the alternative hypothesis is rejected. This agrees with the findings of Astin (1993).

From the overall regression model where EMS is the dependent variable and the three independent variables (CUS, CUL and CUR) were combined to show the overall effectiveness of the marketing mix strategies, the coefficient of correlation (R) is $28.8 \%$ which means that there is a $28.8 \%$ positive relationship between EMS and customer satisfaction, customer loyalty and customer retention. The F-statistic of 5.594 is significant at $5 \%$ level of error with a probability of 0.000 is less that $5 \%$ or 0.05 . This means that there is a positive and significant relationship between the effectiveness of Zenith marketing mix strategies between customer satisfaction, customer loyalty and customer retention. This implies that Zenith marketing mix strategies are effective and therefore rejecting the hypothesis that the marketing mix strategy of Zenith was not effective.

\section{Customer Satisfaction}

\section{SUMMARY OF FINDINGS}

The results of the analysis show that each of the elements in the marketing mix strategies influences customer satisfaction but the most influential or significant elements were product and process followed by personnel. This relationship shows that Zenith Bank marketing mix strategies were effective in meeting customer satisfaction. However, products, processes and personnel elements were significantly effective in meeting customer satisfaction.

\section{CONCLUSION}

The effectiveness of the overall marketing mix strategies of a service marketing organization is determined by the impact of each of the elements that makes up the marketing mix. The analysis of the effectiveness of the marketing mix strategies of Zenith Bank has shown that 
though each of the elements of the marketing mix strategies comprising of product, price, place, promotion, personnel and process influences the effectiveness of the Bank marketing mix strategies, product, process and personnel as well as price were more significant in meeting customer satisfaction, customer loyalty and customer retention respectively which are the major parameters for measuring the marketing performance of service marketing organizations.

The overall results of this research show that there is a significant positive relationship between the effectiveness of Zenith marketing mix strategies and the three major parameters of customer satisfaction, customer loyalty and customer retention. This implies that Zenith marketing mix strategies were effective.

\section{RECOMMENDATIONS}

Based on the findings, this study proffers the following recommendation:

1. Zenith Bank management should re-examine and improve on the price, place and promotion elements in the marketing mix strategies that though were effective but not significantly effective.

2. Though process, products and personnel were positively significantly effective, the Bank should continue to improve on these important elements so as to continue to meet and even exceed its present levels of customer satisfaction, loyalty and retention.

3. To improve on the effectiveness of the Bank marketing mix strategy, the Bank should provide maximum data security to prevent any vulnerability to hacking.

4. The Bank should continuously train its personnel and provide the latest reliable facilities to ensure error free transactions to reduce customer complaints.

5. The Bank should regularly provide technical back-up and servicing of ATM outlets to avoid frequent breakdown of ATM machines to avoid the frustration suffered by customers that could lead to dissatisfaction, disloyalty and customer drop out.

6. The Bank should proactively and regularly estimate cash demand trends especially during week-end by relying on the Miller-Orr (1980) model of cash management at bank branches to avoid cash shortage at ATM cash dispensing outlets.

7. The Bank should increase its corporate social responsibility by sponsorship of social events that could increase its visibility, attract and retain customers.

8. The Bank should improve its products by proving new products that could attract and meet customer expectation.

9. On the pricing element of the Bank marketing mix strategies, the Bank should provide fee discounts to customers based on value and volume of transactions.

\section{CONTRIBUTIONS TO KNOWLEDGE}

The research contributed to knowledge by revealing that rather than emphasizing so much on marketing promotion and pricing as strategies for attracting, cultivating customer satisfaction and loyalty, the most important elements in the marketing mix strategies that contribute to customer satisfaction and loyalty are product, process and personnel. On customer retention the study has revealed that the most important elements in the order of priority in the marketing mix strategies that contribute more to customer retention are the process, product, price and promotion rather than personnel and place. This implies that process, product and personnel are very significant in the effectiveness of the bank marketing mix strategy. This contribution to knowledge has implications for bank marketing management planning towards enhancing customer satisfaction, loyalty and retention in the Nigerian banking environment. 


\section{References}

Adebowale Biodun .A. (2015).Marketing of banking services and consumer satisfaction in the Nigerian banking industry. British Journal of Marketing Studies, 3(3) pp 1 - 11.

Adeleye, Olawale and Adeleke (2015). Post consolidation analysis of service marketing mix and bank performance in Nigeria. International Journal of Scientific and Engineering Research, 6(5) 2015.

Akinyele, S. T. and O.S. Opeyemi (2011). Impact of marketing strategies on bank performance. Lap Lambert Academic Publishing, May 24, 2011.

Astin (1993) What matters in college? Four critical years revisited. San Francisco: Jossey-Bass.

Babin Pokharel (2011), Customer relationship management: Related theories, challenges and application in banking sector, Banking Journal, Vol.1, Issue-1, pp.19-28.

Booms, B., H., and Bitner, M., J., 1981. Marketing strategies and organization structures for service firms, in Donnelly, J., H., and George, W., R., (eds). Marketing of Services. Chicago: American Marketing Association.

Cengiz, E. and Yayla, H.E. (2007). The effect of marketing mix on positive word of mouth communication: evidence from accounting offices in Turkey. Innovative Marketing, Volume 3, Issue 4.

Cochran, W.G (1963). Sampling techniques.@nd edition, N.Y, John Wiley and Sons Inc.

Cronbach L.J. (1951). Coefficient alpha and the internal structure of tests. Psychometrika 16(3) 297 - 334

Culliton, J.W. (1948). The Management of Marketing Costs. Boston: Division of Research, Graduate School of Business Administration, Harvard University, 1948.

Edwin Anyim (2018), Several strategies of markets in the Nigerian Banking Industry. Business and Economics Journal, Vol. 9(2), 359.

Gronroos, C. (2000) Service management and marketing: A customer relationship management approach. John Wiley and Sons, Ltd., Hoboken.

https://www.researchgate.net/publication/215915793_Service_Management_and_Marketing_A_Customer_Relati onship_Management_Approach.

Islam, F. and M. Rahman, M (2015). Service marketing mix and their impact on bank marketing performance: a case study on Janata Bank ltd, Bangladesh. Journal for worldwide holistic sustainable development, Issue1 (1),2015

Jean-Jacques Lambin (2013). Changing market relationships in the internet age. Business and Economics. http://books.openedition.org/pucl/1647?lang=en

Kalyanam, K. and Mclutye, S. (2002). The e-marketing Mix: A contribution of the e-tailing wars, Santa Clara University. Journal of the Academy of Marketing Science. Volume 30, No. 4, pages 483-495. DOI:

10.1177/009207002236924.

Kotler, P. and Keller, K.L. 2009.Marketing management (13"th end). New Jersey: Pearson Education Inc, Upper Saddle River.

Kotler, P. and Armstrong, G.M. (2010). Principles of marketing Pearson custom business resources series, $13^{\text {th }}$ Edition, The Prentice Hall International Series in Marketing.

Kotler, P. and Armstrong, G. (2013) Principle of marketing. 15th Edition, Prentice Hall.

CBN (2014). Annual reports and statistics, Lagos, (FAQS)

Likert, R. (1967). The human organization, New York: McGraw-Hill.

Lovelock, C, Wirtz, V., and Patricia, C. (2000). Essentials of Services Marketing. 12 ${ }^{\text {th }}$ Edition.

Marieluise Guzzoni (2005). Models of Service Marketing - A study on the marketing functions of project workers in knowledge-intensive companies. LUP student papers, LUND UNIVERSITY LIBRARIES.

Michael Treacy and Fred Wieserma (1996). The discipline of market leaders: choose your customers, narrow your focus and dominate your market. Basic books; expanded edition.

Nunally, J.C. (1978). Psychometric theory (2nd ed.). New York, NY: McGraw-Hill.

Nwankwo, G. (1991). Bank management: principles and practice. Malthouse Press Ltd Lagos.

Ogunnaike, O., Olaleke, Taiye, T.B, Sholarin Adeniyi and Odubela, 0.0. (2014). 
Empirical analysis of marketing mix strategy and student loyalty in education marketing. Mediterranean Journal of Social Sciences. MCSER Publishing, Rome-Italy, Vol. 5, No. 23, 2014.

Oni, B. (2002). Capacity building for universal banking: the challenge of human capital management. The Journal of Banking and Finance 5(2), 19 - 24.

Oyefunji, T. (2003). Financial distress in banks, nature and implications. The Nigerian Banker, April - June. 5.

Parasuraman, A., Zeithaml, V. A., \& Berry, L. L. (1985). A conceptual model of service quality and its implications for future research. Journal of Marketing, 49(4), 10.

Schneider, B. (1991), Service quality and profits: Can you have your cake and eat it too? Human Resource Planning, 14 (2), 151-157.

Singh, M. (2012). Marketing mix of 4P's for competitive advantage. IOSR Journal of Business and Management (IOSRJBM). Vol. 3, Issue 6. http://iosrjournals.org/iosr-jbm/papers/vol3-issues6/G0364045.pdf?id=5454.

Verhoef, P.C. and Langerak, F. (2002). Further thoughts on CRM: Strategically embedding customer relationship management in 0rganizations. Erasmus University Rotterdam (EUR) - Rotterdam School of Management (RSM).

Zeithaml, V.A., Rust, R.T. and Lemon, K.N. (2001). The customer pyramid: Creating and serving profitable customers https://doi.org/10.2307/41166104. California Management Review.

Zenith Bank: https://www.zenithbank.com accessed 6 ${ }^{\text {th }}$ October 6, 2018.

Zenith Bank (2017). Annual Financial Report: 2017) 